\title{
Comparative Analysis of Production Costs and Revenue on the Banana Planting Season in Taiwan
}

\author{
Te-Sheng Lin'1, Chun-Nan Lin², Ke-Chung Peng² \\ ${ }^{1}$ Department of Plant Industry, National Pingtung University of Science and Technology Industry, Taiwan \\ ${ }^{2}$ Department of Agribusiness Management, National Pingtung University of Science and Technology, Taiwan \\ Email: eric.wasu@gmail.com
}

How to cite this paper: Lin, T.-S., Lin, C.-N. and Peng, K.-C. (2019) Comparative Analysis of Production Costs and Revenue on the Banana Planting Season in Taiwan. Open Access Library Journal, 6: e5180. https://doi.org/10.4236/oalib.1105180

Received: January 11, 2019

Accepted: January 26, 2019

Published: January 29, 2019

Copyright $\odot 2019$ by author(s) and Open Access Library Inc.

This work is licensed under the Creative Commons Attribution International License (CC BY 4.0).

http://creativecommons.org/licenses/by/4.0/

\begin{abstract}
The planting season of crops has always been an important research topic to the revenue. This research aims to use bananas as a case study and use the principle of break-even analysis to explore the issues of profit and loss and market potential of the spring-summer's bananas and the autumn-winter's bananas in Taiwan. The secondary data were collected from Council of Agriculture, Executive Yuan Taiwan during 2011-2015. The concept of break-even analysis was applied in this research as the research methodology. The empirical results found that the break-even points of spring-summer's bananas and autumn-winter's bananas during 2010-2015 were decreasing due to the increase of an average market selling price. However, the spring-summer's bananas have a higher revenue ratio than the other season. Therefore, the bananas' growers in Taiwan should plant bananas during the spring-summer season in order to gain a higher profit.
\end{abstract}

\section{Subject Area}

Economic System

\section{Keywords}

Production Costs, Revenue, Break-Even Analysis, Planting Season, Banana Industry

\section{Introduction}

Banana is the most characteristic tropical fruit in the tropical region of Taiwan. Bananas grow fast, which are planted this year, and this year they will be harvested. Since banana is the world's largest trade and consumption of fresh fruit, 
Food and Agriculture Organization of the United Nations (FAO) has ranked banana as the fourth largest fruit in the developing countries, after rice, wheat, and corn. According to FAO's statistics (2014) [1], the harvest area of bananas in the world was around 5.39 million hectares. The banana's production was about 112 million tons. Furthermore, an import and export values accounted for 29.35 billion US dollars, after wheat, soybeans, and corn.

The banana is one of the most important tropical fruits in Taiwan, mainly grown in Pingtung, Kaohsiung, Chiayi, Nantou, and Taichung. According to a planting time period, there are two main seasons: a spring-summer's banana together with an autumn-winter's banana.

This research aims to use the principle of break-even analysis to explore the issues of profits and losses and to market the potential of the spring-summer's bananas and the autumn-winter's bananas in Taiwan. The secondary data collected from Council of Agriculture, Executive Yuan Taiwan were used to analyze the changes in costs and revenues based on the concept of the break-even analysis in order to support the farmers to make a right decision. The results provide meaningful and important information to improve the banana's industry in Taiwan as well.

\section{Literature Review}

Banana is the world's largest fruit and is the most controversial crop in Taiwan. Refer to Taiwan's Agricultural Statistics Report in 2015, a cultivation area of bananas accounted for 14,605.44 hectares, and a selling price was about NT\$27/kg. In addition, the spring-summer's bananas, and the autumn-winter's bananas had annual profits about NT\$261,043/ha and NT\$375,769/ha, respectively.

The banana has been considered as a year round agriculture production in Taiwan. The main production period is normally from February to June because of no heavy typhoon and cold weather. Moreover, there are higher demands from both local and foreign markets. The production outputs for this season accounted for 60 - 70 percent of all annual outputs, especially the spring-autumn's bananas grown in Kaohsiung and Pingtung County. Nevertheless, the farmlands in Taichung, Chiayi, and Nantou County are mostly hillside, consequence of no irrigation facilities, and difficult to adjust the production period. Therefore, most of the farmers prefer growing the autumn-winter's bananas due to suitable cultivation land and appropriate climate. Most of the production period is from September to December.

The banana is not only the important economic fruits, but also the largest fresh exporting agricultural products in Taiwan. The banana of Taiwan has increasingly exported to Japanese market for a hundred years. In 1967, the export was the highest volume, accounting for 51.95 million US dollars (12 kg per hectare). In addition, the harvest areas were more than 50,000 hectares (Council of Agriculture, Executive Yuan Taiwan, 2017) [2].

Taiwan's economic structure has undergone a transition from agriculture to 
industry. After 1971, Taiwan's economic structure dramatically changed a lot, a large number of rural labor forces moved far away from their hometown to work in an industrial estate, resulting in labor shortage in the rural areas and the rising wages. The banana's production dramatically suffered a lot, facing with a yellow leaf disease, which causes a huge reduction in banana's yields. Moreover, the selling price of banana in foreign markets like Japan, the Philippine and the South America was cheaper. The banana's growers had less profit and gave up easily towards the banana's industry.

In summary of the above literature review, there were many scholars have published more research regarding banana's industry in Taiwan, such as diseases resistant (Chen et al., 2014; Chan et al., 2013; Hwang, 2002) [3] [4] [5] and to establish the production system (Chiang et al., 2012; Lee et al., 2013) [6] [7], and industrial economic (Wang, 2012) [8]. There were also many publications in using break-even analysis to study costs and revenues of banana industry (Chen and Day, 2009; Mahama et al., 2013; Lee et al., 2015; Guo et al., 2011) [9] [10] [11] [12]. However, there was no any research analyzing the situation of profit and loss and market competition potential of the banana's industry in Taiwan.

\section{Methodology}

This study used the break-even analysis method to analyze secondary data. The secondary data were collected from the Agricultural Statistic Annual Report, Council of Agriculture, Executive Yuan Taiwan during 2010-2015 in terms of the production costs and revenues of banana industry in Taiwan.

The financial analysis steps of this research method are as follows: a financial analysis requires identification of all revenues and costs streams over the life of the project. For the current study, the costs include fixed costs and variable costs. The fixed costs constitute the capital outlay of the firms. The fixed costs include land, structure and buildings, machinery, insurance, payment of interest and rent.

In fact, the fixed inputs decline in value or productivity as the annual use of the machinery, equipment, and buildings increase. Alternatively, these costs were completely excluded in one season. The annual depreciated values were estimated and used in undertaking the undiscounted break-even analysis. The depreciated values of the fixed inputs were summed to give the total fixed cost of a production cycle.

The variable cost can be divided into production cost, overhead cost, and research and development's cost. Overhead costs included the costs of indirect materials, indirect labour (management and staff officers), office expenses, and maintenance of vehicles. These costs were summed up as the total variable cost (TVC). The total cost (TC) of a production cycle, therefore, is the sum of the total fixed cost (TFC) and total variable cost (TVC). Total revenue is the cash value realized from the sales of bananas during the accounting period (a production cycle). To arrive at the sales revenue, the total quantity of bananas sold (Q) was multiplied by the until price $(\mathrm{P})$ of the product. Thus, $\mathrm{TR}=\mathrm{Q} \times \mathrm{P}$, where $\mathrm{TR}$ is total revenue. Break-even analysis $(\mathrm{B} / \mathrm{E})$ is normally used to establish the relation- 
ship between fixed costs, variable costs, sales revenue, and profit. The break-even point is derived from the revenue of the farms. It is assumed that the banana farm in Taiwan areas operating in a competitive local market; considered as a price taker. At the break-even point, the total cost of production is equal to the total revenue.

\section{Results and Discussion}

According to the secondary data and break-even analysis, we can get the production analysis of the spring-summer's banana farms, and autumn-winter's banana in Taiwan. The outputs were about 33 tons per hectare, and the total revenue was about NT\$380,000 in 2010 and NT\$ 990,000 in 2014, and NT\$ 620,000 in 2015. The overall approach is increasing due to the banana price. The total cost was about NT\$387,000 per hectare each year except in 2010 due to typhoon. Therefore, the profits were gradually increasing, as shown in Table 1.

According to the secondary data and break-even analysis, we can get the production costs per hectare of the spring-summer's bananas in Taiwan during 2010-2015. The production costs were about NT\$168,000 per hectare, averagely, and slightly declined year by year. The costs of chemical and herbicide were increasing, up to NT\$23,439 in 2015. The fixed costs remained at about NT\$ 5200/ha. The costs of man-hour labor were decreasing year by year due to the increase of the family labor, as shown in Table 2.

According to the secondary data and break-even analysis, we can get the production costs and benefits of the autumn-winter's bananas during 2010-2015. The yields of the autumn-winter's bananas were about 20 tons/year, and the total revenues were increasing year by year, up to NT\$ 540,000 in 2014 . The total costs were about NT\$260,000. The net profits were negative in 2010 and 2011 due to a typhoon. The remaining periods were surplus, and increased NT\$290,000 at the net profit rate of $117.56 \%$, as shown in Table 3.

Table 1. The production costs and revenues per hectare of the spring-summer's bananas in Taiwan during 2010-2015.

\begin{tabular}{cccccc}
\hline Year & $\begin{array}{c}\text { Production Costs } \\
\text { Per Units } \\
(\mathrm{kg} / \mathrm{ha})\end{array}$ & $\begin{array}{c}\text { Gross Output } \\
\text { Value } \\
(\mathrm{NT} \$ \mathrm{ha})\end{array}$ & $\begin{array}{c}\text { Total Costs } \\
(\mathrm{NT} / \mathrm{ha})\end{array}$ & $\begin{array}{c}\text { Net Profit } \\
(\mathrm{NT} \$ \mathrm{ha})\end{array}$ & $\begin{array}{c}\text { Profit Rate } \\
(\%)\end{array}$ \\
\hline 2010 & 33,481 & 380,670 & 413,672 & $(33,002)$ & $(7.98)$ \\
2011 & 34,159 & 418,766 & 403,913 & 14,853 & 3.68 \\
2012 & 34,804 & 586,354 & 392,466 & 193,888 & 49.40 \\
2013 & 33,492 & 888,938 & 372,992 & 515,946 & 138.33 \\
2014 & 33,067 & 989,929 & 370,601 & 619,328 & 167.11 \\
2015 & 31,158 & 625,958 & 369,246 & 256,712 & 69.52 \\
\hline
\end{tabular}

Source: Council of Agriculture, Executive Yuan Taiwan (2017). Note: The negative numbers were showed in parentheses. 
Table 2. The production costs per hectare of the spring-summer's bananas in Taiwan during 2010-2015. Unit: NT\$/ha.

\begin{tabular}{|c|c|c|c|c|c|c|}
\hline Type & 2010 & 2011 & 2012 & 2013 & 2014 & 2015 \\
\hline Production costs & 173,626 & 170,099 & 171,664 & 165,478 & 163,541 & 164,810 \\
\hline Direct costs & 68,516 & 165,007 & 166,493 & 160,246 & 158,254 & 159,498 \\
\hline Established expenditure & 22,978 & 23,640 & 23,846 & 22,799 & 22,133 & 22,733 \\
\hline Fertilizer & 46,797 & 45,464 & 46,677 & 45,551 & 45,759 & 46,119 \\
\hline Contract labor & 9908 & 8624 & 8736 & 7550 & 7645 & 8572 \\
\hline Chemical \& herbicide & 20,972 & 21,649 & 22,767 & 22,500 & 22,998 & 23,439 \\
\hline Energy & 4546 & 4544 & 4695 & 4551 & 4529 & 4280 \\
\hline Materials of equipment & 63,315 & 60,518 & 59,772 & 57,295 & 55,190 & 54,355 \\
\hline Irrigation charge & - & 568 & - & - & - & - \\
\hline Extra charge (fixed costs) & 5110 & 5092 & 5171 & 5232 & 5287 & 5312 \\
\hline $\begin{array}{c}\text { Agriculture facilities } \\
\text { expenditure (depreciation) }\end{array}$ & 1589 & 1634 & 1663 & 1693 & 1707 & 1696 \\
\hline $\begin{array}{l}\text { Agriculture facilities } \\
\text { expenditure }\end{array}$ & 530 & 545 & 555 & 565 & 568 & 565 \\
\hline Farming tools (depreciation) & 2243 & 2185 & 2215 & 2231 & 2259 & 2288 \\
\hline Farming tools expenditure & 748 & 728 & 738 & 743 & 753 & 763 \\
\hline Taxes & - & - & - & - & - & - \\
\hline Labor costs & 208,712 & 202,826 & 193,932 & 182,465 & 180,666 & 179,488 \\
\hline Man-hour labor & 208,712 & 202,826 & 193,932 & 182,465 & 180,666 & 179,488 \\
\hline Family labor & 172,923 & 166,357 & 165,033 & 142,314 & 148,504 & 164,059 \\
\hline Contract labor & 35,789 & 36,469 & 28,899 & 40,151 & 32,162 & 15,429 \\
\hline
\end{tabular}

Source: Council of Agriculture, Executive Yuan Taiwan (2017).

Table 3. The production costs and benefits of the autumn-winter's bananas during 2010-2015.

\begin{tabular}{cccccc}
\hline Year & $\begin{array}{c}\text { Production } \\
\text { Costs } \\
(\mathrm{kg} / \mathrm{ha})\end{array}$ & $\begin{array}{c}\text { Gross Output } \\
\text { Value } \\
(\mathrm{NT} \$ \mathrm{ha})\end{array}$ & $\begin{array}{c}\text { Total Costs } \\
(\mathrm{NT} / \mathrm{ha})\end{array}$ & $\begin{array}{c}\text { Net Profit } \\
(\mathrm{NT} / \mathrm{ha})\end{array}$ & $\begin{array}{c}\text { Profit Rates } \\
(\%)\end{array}$ \\
\hline 2010 & 14,473 & 194,731 & 263,713 & $(68,982)$ & $(26.16)$ \\
2011 & 18,275 & 239,726 & 263,286 & $(23,560)$ & $(8.95)$ \\
2012 & 20,880 & 279,489 & 273,666 & 5823 & 2.13 \\
2013 & 20,615 & 380,042 & 256,780 & 123,262 & 48.00 \\
2014 & 19,821 & 541,413 & 248,854 & 292,559 & 117.56 \\
2015 & 20,388 & 503,027 & 254,184 & 248,843 & 97.90 \\
\hline
\end{tabular}

Source: Council of Agriculture, Executive Yuan Taiwan (2017). Note: The negative numbers were showed in parentheses.

According to the secondary data and break-even analysis, we can got the production costs per hectare of the autumn-winter's bananas in Taiwan during 
2010-2015. On the production costs and benefits of the autumn-winter's bananas during 2010-2015, the production costs were decreasing year by year, mainly due to the decrease of direct expenditure, among which the costs of fertilizer and materials of equipment were large, the indirect costs are maintained at about $4600 \mathrm{TW} \$$, and the labor cost is declining, mainly from the employee's fee reduction, as shown in Table 4.

\section{Conclusions and Suggestions}

The results of this study find that the seasons for banana planting in Taiwan are different, and the profit from bananas is different. In this paper, the BEP analysis principle was used to explore the operation efficiency and market potential of the spring-summer's bananas and autumn-winter's bananas in Taiwan. From 2011 to 2015, the overall production values of bananas were increasing in Taiwan, and the costs were decreasing. The overall net profits of both the spring-summer's bananas and the autumn-winter's bananas were increasing, except for the damages by the typhoon.

In addition, the price of bananas is also an important influence. The analysis of this research finds that the increase in profits is mainly due to the increase of

Table 4. Production costs per hectare of the autumn-winter's bananas in Taiwan during 2010-2015. Unit: NT\$/ha.

\begin{tabular}{|c|c|c|c|c|c|c|}
\hline Type & 2010 & 2011 & 2012 & 2013 & 2014 & 2015 \\
\hline Production costs & 111,797 & 111,692 & 118,492 & 107,869 & 103,038 & 104,502 \\
\hline Direct costs & 107,362 & 107,103 & 113,821 & 103,110 & 98,253 & 99,660 \\
\hline Established expenditure & 14,741 & 15,658 & 18,168 & 14,955 & 15,067 & 15,175 \\
\hline Fertilizer & 35,810 & 33,937 & 34,920 & 32,895 & 32,130 & 32,518 \\
\hline Contract labor & 147 & - & 638 & - & - & - \\
\hline Chemical \& herbicide & 10,560 & 10,451 & 11,588 & 11,513 & 11,931 & 12,235 \\
\hline Energy & 4251 & 4011 & 4128 & 4173 & 4016 & 4090 \\
\hline Materials of equipment & 41,853 & 42,873 & 44,379 & 39,574 & 35,109 & 35,642 \\
\hline Irrigation charge & - & 173 & - & - & - & - \\
\hline Extra charges (fixed costs) & 4435 & 4589 & 4671 & 4759 & 4785 & 4842 \\
\hline $\begin{array}{l}\text { Agriculture facilities expenditure } \\
\text { (depreciation) }\end{array}$ & 1623 & 1740 & 1790 & 1827 & 1841 & 1853 \\
\hline Agriculture facilities expenditure & 541 & 580 & 596 & 610 & 613 & 618 \\
\hline Farming tools (depreciation) & 1703 & 1702 & 1714 & 1741 & 1748 & 1778 \\
\hline Farming tools expenditure & 568 & 567 & 571 & 581 & 583 & 593 \\
\hline Labor costs & 130,375 & 131,037 & 133,050 & 126,523 & 123,847 & 127,366 \\
\hline Man-hour labor & 130,375 & 131,037 & 133,050 & 126,523 & 123,847 & 127,366 \\
\hline Family labor & 108,409 & 104,681 & 119,730 & 108,373 & 103,571 & 107,838 \\
\hline Employee fees & 21,966 & 26,356 & 13,320 & 18,150 & 20,276 & 19,528 \\
\hline
\end{tabular}

Source: Council of Agriculture, Executive Yuan Taiwan (2017). 
the selling price of the bananas. The yields were quite stable, except for the year which faced with a natural disaster. The operating costs were decreasing slowly. Therefore, the banana price plays the impact role in the decrease of the BEP.

The marginal revenue rates of the autumn-winter's banana were higher than the spring-summer's bananas. The growing season of the spring-summer's bananas has fewer typhoons and other natural disasters than the autumn-winter's bananas.

The temperature and related climate were also more suitable in the spring-summer's bananas than the autumn-winter's bananas. The yields of spring-summer's bananas were significantly higher than the autumn-winter bananas. Therefore, the overall marginal revenue rates of spring-summer's bananas were also significantly higher than the autumn-winter's bananas.

Taiwan has a great influence on the cultivation of bananas during the typhoon and windy seasons. As the spring-summer's bananas are always encountered by typhoons, the market competition and potential competition are higher than the autumn-winter's bananas. The farmers should avoid the windy seasons while growing bananas on their own areas in order to increase the revenue ratios.

\section{Conflicts of Interest}

The authors declare no conflicts of interest regarding the publication of this paper.

\section{References}

[1] Food and Agriculture Organization of the United Nations (FAO) (2014) Databases. http://www.fao.org/statistics/databases/en/

[2] Council of Agriculture, Executive Yuan Taiwan (2017) Agricultural Statistic Annual Report. Yearly Report of Taiwan's Agriculture.

https://eng.coa.gov.tw/ws.php?id=8821

[3] Chen, H.W., Do, Y.Y., Huang, P.L. and Wu, M.T. (2014) Current Developments in Genetically Modified Bananas. Journal of the Taiwan Society for Horticultural Science, 60, 1-10.

[4] Chan, H.T., Chia, M.Y., Pang, V.F., Jeng, C.R., Do, Y.Y. and Huang, P.L. (2013) Oral Immunogenicity of Porcine Reproductive and Respiratory Syndrome Virus Antigen Expressed in Transgenic Banana. Plant Biotechnology Journal, 11, 315-324. https://doi.org/10.1111/pbi.12015

[5] Hwang, S.C. (2002) Application of Tissue Culture Technology for Controlling Fusarium Wilt of Banana. Plant Pathology Bulletin, 11, 57-61.

[6] Chiang, S.C., Chang, C.M., Chen, H.P., Chen, M.J. and Chao, C.P. (2012) Research and Integrated Management of Organic Banana Production System. Proceedings of the International Conference on the Development of Organic Agriculture Industry, 113, 131-148.

[7] Lee, S.Y., Chen, C.Y. and Chao, C.P. (2013) Germplasm Diversity and Cultivation Management of Taiwan Banana. Taiwan Natural Science, 32, 24-33.

[8] Wang, J.S. (2012) The Study on the Production and Consumption of Banana at Wu-Fang Area during the Period of Japanese Governed Taiwan. Chaoyang Journal 
of Humanities and Social Science, 10, 1-28.

[9] Chen, S.F. and Day, D.T. (2009) A Case Study of Organic Vegetable Farm Operated Achievement. Bulletin of Taichung District Agricultural Research and Extension Station, 105, 13-21.

[10] Mahama, E.A., Andah, E.K., Amegashie, D.P.K. and Mensah-Bonsu, A. (2013) Break Even Analysis of Broiler Production in the Accra-Tema and Kumasi Areas. European Scientific Journal, 3, 545-552.

[11] Lee, Y.C., Tai, C.F., Li, C.N. and Peng, K.C. (2015) Operating Efficiency of Litchi Industry in Taiwan. Journal of the Agricultural Association of Taiwan, 17, 192-214.

[12] Guo, S.M., Wu, Y.P., Tang, H.C., Yu, H., Wang, C., Zhao, C.P. and Ma, H.Y. (2011) Estimating Break-Even Point and Analyzing Competitive Potential on Dairy Farms of China. China Dairy Cattle, 3, 35-38. 